M.G.S. B.M.

Palm Warbler

15

Water-thrush

Connecticut Warbler

Mourning Warbler

Wilson's Warbler

Redstart

Brewer's Blackbird

Red-winged Blackbird

Baltimore Oriole

Cowbird

Evening Grosbeak

Purple Finch

Hoary Redpoll

\section{5}

.......

1

.......

4

4

5

13

6

3

\title{
Mrs. Edith Orman
}

We are pleased to have received again from Mrs. Edith Orman, teacher at Walton School, gift renewals to twelve of her students in the Stoughton district. This is the third successive year that Mrs. Orman has done this in order that each family in her district may have the "Blue Jay" in the home. It has been for this reason that her daughter, Constance Orman, has been listed among the Patrons for 1953.

\section{QU'APPELLE VALLEY}

(Continued from Page 11)

different kinds make their home here and many Woodpeckers, and the tiny Hummingbird.

Many animals may still be seen by the observant. Herds of Deer in some seasons, at times single graceful Whitetails bound across the meadow. Lynx have rarely been seen, also Red Foxes, Porcupines, Woodchucks, badgers and coyotes in deep dens in the ravines. Buffalo wallows still show where those noble animals frequented the many springs.

Turtles are found near the river, and the small Newts and colorful Garter Snakes have not all been exterminated. Gophers, plain and stripped, red and grey Squirrels and tiny Chipmunks still make their homes here.

We have made our homes here for over forty years, and have noted these things and many others in our beloved valley, once a place where bands of horses were herded, now more given over to cattle raising.

M.G.S. B.MI.

$\begin{array}{lrr}\text { Common Redpoll .................... } & 313 & 563 \\ \text { Pine Siskin ..................................... } 17 & 99\end{array}$

American Goldfinch ................ 3

Savannah Sparrow ......................... 36

Vesper Sparrow ................................... 32

Slate-colored Junco ................. $338 \quad 335$

Tree Sparrow ................................. 846

Chipping Sparrow ..................... $33 \quad 23$

Clay-colored Sparrow ............. $11 \quad 106$

Harris's Sparrow ......................... 11 5

Gambel's Sparrow ...................... 616

1 White-throated Sparrow..... $49 \quad 40$

Fox Sparrow .................................... 5

Lincoln Sparrow ................................. 95

Swamp Sparrow ................................ 16

Song Sparrow .................................. $7 \quad 79$

Total Individuals ...................1837 1628

Total Species ............................ $60 \quad 45$

Grand Total Species .......................... 79

Grand Total Individuals ...............3465

\section{VISITORS}

By Dora Bardal, Wynyard

There is a lot of bush around here and consequently some of the birds that do not linger on the bald prairie are quite common. We haven't seen Blue Jays for several years, but they used to nest here. Perhaps that is because the Magpies are so numerous now!

Two years ago in the fall, just before the Bluebirds left us and after the snow came, we saw a solitary Bluebird with a rust colored breast. Would that be the Arkansas Bluebird? (It probably was an Eastern Bluebird, which appear in Manitoba, and rarely in Saskatchewan. "A famous writer has described the Eastern Bluebird as 'The sky above, the earth beneath' referring to blue back and red breast. Following this figure of speech, the Mountain Bluebird is purely celestial with no earthly contamination." - Taverner. Ed.)

We have seen flocks of Golden Plovers, and once, several years ago, a flock of Starlings. During the past winter Grosbeaks were common, feeding on the dried-up Saskatoon and Chokecherry berries. We recently have had a Canada Jay with us. Some winters we do not see them at all. 